Article

\title{
Emerging Governance Architectures in Global Health: Do Metagovernance Norms Explain Inter-Organisational Convergence?
}

\author{
Anna Holzscheiter ${ }^{1,2,3, *}$, Thurid Bahr ${ }^{1,2,3}$ and Laura Pantzerhielm ${ }^{2,3}$ \\ ${ }^{1}$ Department of Political and Social Sciences, Freie Universität Berlin, 14195 Berlin, Germany; \\ E-Mails: anna.holzscheiter@fu-berlin.de (A.H.), thuridbahr@zedat.fu-berlin.de (T.B.) \\ ${ }^{2}$ Junior Research Group Governance for Global Health, Freie Universität Berlin, 14195 Berlin, Germany; \\ E-Mail: laura.pantzerhielm@wzb.eu \\ ${ }^{3}$ WZB Berlin Social Science Center, 10785 Berlin, Germany \\ * Corresponding author
}

Submitted: 21 January 2016 | Accepted: 11 May 2016 | Published: 11 August 2016

\begin{abstract}
This paper proposes a theoretical account of institutional transformation and the emergence of order in global interorganisational relations, which is centred on the concept of "metagovernance". It does so by theorising on the advent of governance architectures in global health governance-relationships between international organisations (IOs) in this field that are stable over time. Global health governance is routinely portrayed as an exceptionally fragmented field of international cooperation with a perceived lack of synergy and choreography between international and transnational organisations. However, our paper starts from the observation that there are also movements of convergence between IOs. We seek to explain these by looking at the effects of international norms that define good global governance as orderly and harmonised global governance. We conceptualize such norms as "metagovernance norms" that are enacted in reflexive practices which govern and order the relationships between IOs. Empirically, this paper traces changing interactions and institutional arrangements between IOs (World Health Organization; World Bank; Gavi, the Vaccine Alliance; and the Global Fund to Fight AIDS, Tuberculosis and Malaria) in global health governance since the late 1940 s and shows how patterns therein reflect and (re)produce broader discursive perceptions of what "health" is about and how the governance thereof ought to be organised.
\end{abstract}

\section{Keywords}

discourses; global health; international organisations; metagovernance; norms

\section{Issue}

This article is part of the issue "Supranational Institutions and Governance in an Era of Uncertain Norms", edited by Russell Alan Williams (Memorial University, Canada) and Reeta Tremblay (University of Victoria, Canada).

(C) 2016 by the authors; licensee Cogitatio (Lisbon, Portugal). This article is licensed under a Creative Commons Attribution 4.0 International License (CC BY).

\section{Introduction}

In global governance scholarship, it is an almost ritualistic acknowledgement that contemporary international relations are characterised by an escalating institutional fragmentation, competing/intersecting spheres of authority and the resulting pluralism of norm, rules and implementation structures. As a result, debates on how to govern the relationships between a plurality of actors with overlapping mandates and missions have proliferated which testify to the search for good governance norms promising to reorder fragmented, pluralist governance fields (Biermann, Pattberg, van Asselt, \& Zelli, 2009; Drezner, 2007; Holzscheiter, 2010; Rosenau, 2004). An allegedly pathological complexity is also routinely diagnosed in global health governance. Global governance structures that were created for the provision of public 
goods in the health area-particularly the eradication of infectious diseases, such as HIV-are emblematic of a core characteristic of global governance in the $21^{\text {st }}$ century: the simultaneous drive of state and non-state actors towards more international order and more coherent institutional architectures on the one hand and on-going contestation and erosion of these institutional constellations on the other. While some call it a dilemma (Karns \& Mingst, 2004), others see a dialectic between these two processes (Cerny, 2010; Hülsemeyer, 2003; Rosenau, 2000, p. 177). Traditional intergovernmental organisations and new forms of governance with or without the state, according to the literature, find themselves caught between their desire for autonomy on the one hand and recognition of increasing inter-organisational interdependence on the other. ${ }^{1}$

Global health governance often figures as a prime example of the much researched general trend towards proliferation and pluralisation of institutional actors in global governance fields since the late 1990s (Inoue \& Drori, 2006, pp. 205-206). Scholarly engagement with these empirical transformations-in global health policy studies and International Relations (IR) alike-has shown a tremendous propensity towards emphasizing fragmentation, complexity and competition. The end of the Cold War did indeed stimulate a period of excessive experimentation and expansion in international organisation with the creation of a broad array of smaller, issue-specific organisations such as the Global Fund to Fight AIDS, Tuberculosis and Malaria (the Global Fund). Yet, the past decade has seen the emergence of new initiatives, mechanisms and institutions that construct new kinds of inter-organisational cooperation. Metaphorically speaking, these initiatives are meant to provide the "glue" that holds the pieces of the global health mosaic together. Taking this empirical observation as a starting point (section 2), our paper puts forward an alternative account of global health governance that highlights the many instances of convergence between international organisations (IOs) and rule-systems and associates them with shifting discourses on what constitutes good global governance. We propose an alternative conceptual framework for the study of institutional constellations in organisational fields of contemporary global governance (section 3). This framework has two main aspects: First, we develop an empirical-descriptive conceptual toolbox which integrates the study of fragmentation

\footnotetext{
${ }^{1}$ Likewise, there seems to be a discernible divide between IR scholars who welcome institutional fragmentation in the name of legal pluralism and policy-responses more adequate to contemporary problems, and scholars who argue in favour of (re)strengthening more centralised governance architectures in the name of global constitutionalism. Both of these "camps" see either a pluralist or a centralised global order as more effective and legitimate (Shaffer, 2005, p. 684 ff.).
}

and convergence in inter-organisational relations so as to escape the one-sided focus on fragmentation. Pointing to the manifold instances of inter-organisational convergence in global health, we propose an explanatory framework which highlights the role of metagovernance norms and reflexive governance practices to account for transformations in inter-organisational relations and the emergence of governance architectures. That is, we argue for an analysis of historically grown discursive perceptions about how governance ought to be pursued, as well as of how such metagovernance norms are enacted in governance practices to explain convergence between actors, the emergence and (re)organisation of order in organisational fields and the ensuing stabilisation of institutional constellations (section 4). Accordingly, the fourth section of this paper traces changing interactions and institutional arrangements between IOs in global health governance since the late 1940s and shows how patterns therein reflect and (re)produce broader discursive perceptions of what "health" is about and how the governance thereof ought to be organised. More specifically, we illustrate how such norms and perceptions have been a frequent object of contestation and discontinuity and how over time they have included sharply divergent visions, such as the rights-based understandings advanced in the context of the "Health for All"-campaign which was closely connected to the Non-Aligned Movement on the one hand, and later approaches that instead located global health governance in close proximity to quantitative indicators and economic development, innovation and marketisation. Finally, we take a closer look at how - in this historically grown web of meanings and institutions - the numerous contemporary initiatives towards coordination and harmonisation among global health actors came to emerge and how they are underpinned by the formulation of norms that equate good global health governance with orderly and harmonised interactions.

\section{Global Health Governance: Ever Greater Complexity?}

Over the last 20 years, the health sector has evolved into one of the most popular areas of development cooperation ${ }^{2}-$ with a five-fold increase in official development assistance from US\$ 5.6 billion in 1990 (Ravishankar et al., 2009) to US\$ 31.3 billion in 2013 (Murray \& Dieleman, 2014). The observation that health is currently one of the most densely populated

\footnotetext{
2 In comparison with other aid sectors such as agriculture and rural development, this shift in international priorities becomes particularly apparent: see 'Trends in aid to agriculture and rural development between 1971 and 2009', in OECD (2011a) and 'Trends in aid to health between 1971 and 2009', in OECD (2011b).
} 
areas of global governance with about a hundred major organisations can be interpreted as either cause or consequence of this development (Godal, 2005; International Development Association, 2007; Organisation for Economic Co-operation and Development, 2011d; Schieber, Gottret, Fleisher, \& Leive, 2007). Global health governance is therefore routinely described as a "messy" structure (Sidibé, Tanaka, \& Buse, 2010, p. 2) composed of different types of actors with diverging motivations and rationalities. As a consequence, it is no longer self-evident which organisation constitutes the backbone of global health governance. As many claim, the World Health Organization's (WHO) central position is undermined by organisations that compete for legitimacy and influence on global health priorities and national health strategies, such as the World Bank, the Global Fund, the Bill and Melinda Gates Foundation (the Gates Foundation) or global programmes like the U.S. President's Emergency Plan for AIDS Relief (PEPFAR) (Huckel, 2005; Smith, 1995; Taylor, 2002), particularly in developing countries. The complexity of this institutional landscape is especially visible in the global response to HIV/AIDS where numerous governmental and non-governmental, bilateral and multilateral agencies are part of institutional structures created to respond to the challenges presented by the HI-Virus. In a typical high HIV-prevalence country such as Namibia or Zambia between seven and twelve bilateral agencies or AIDS programmes, such as PEPFAR, and six to eight multilateral organisations, such as WHO, United $\mathrm{Na}$ tions Children's Fund (UNICEF), United Nations Population Fund (UNFPA), United Nations Development Programme (UNPD), the World Bank and the Global Fund, are contributing to the national AIDS response (Government of Namibia, 2010; Ministry of Health and Social Services of the Republic of Namibia, 2010; National AIDS Council Zambia, 2014). These external agencies-particularly those belonging to the " $\mathrm{H}^{\prime \prime}{ }^{3}-$ provide around 50 to 90 per cent of the total budget for the national AIDS strategy.

Like few other areas of governance, global health governance reflects a "world that is characterized by increasingly dense, extended and rapidly changing patterns of reciprocal interdependence and by increasingly frequent, but ephemeral interactions across all types of pre-established boundaries, intra- and interorganisational, intra- and intersectional and intra- and international" (Scharpf, 1994, p. 36). In the beginning, the multiplication and fragmentation of sources of authority in global health governance was lauded as an indication of enhanced funding flows, as well as greater

\footnotetext{
${ }^{3}$ The $\mathrm{H} 8$, or Health 8 are those IOs that are typically presented as particularly influential in global health: WHO; The Joint United Nations Programme on HIV and AIDS (UNAIDS); UNICEF; UNFPA; the World Bank; Gavi, the Vaccine Alliance (Gavi); the Global Fund and the European Commission.
}

flexibility in policy-making and implementation. By now, however, the initial enthusiasm for such centrifugal tendencies in development cooperation seems to have decreased in the face of an on-going "implementation crisis" (The Joint United Nations Programme on HIV and AIDS, 2006, p. 53). Both traditional bilateral and multilateral agencies and more recently established programmes and partnerships increasingly lament the multiplication of players, programmes and sources of funding and perceive of them as producing suboptimal outcomes. In this governance area, collective action problems and their implications for effective development cooperation have been widely discussed and recognised for a long time.

As a consequence of the continuing debate on the negative ramifications of institutional fragmentationparticularly the administrative strain they put on already weak domestic governance structures in developing countries-global public health also ranks among those policy fields in which experimentation with rulesystems and instruments of governance has been strongest. International actors are progressively undertaking efforts to streamline their activities and to work towards agreement on a global division of labour and on coherent policies for programming, programme implementation, technical assistance, monitoring and evaluation. Beyond health, this applies to various other densely populated areas of global governance, such as security, humanitarian aid or environmental protection (for health see Holzscheiter, Walt, \& Brugha, 2012). The Organisation for Economic Co-operation and Development (OECD), through its Development Assistance Committee (OECD-DAC) has been a trend-setter in this domain and the major driving force behind the most influential approaches to principles of good governance in development cooperation (cf. Paris Declaration (2005), Accra Agenda for Action (2008) and the Busan Partnership for Effective Development Cooperation (2011c)).

It is a remarkable finding from existing research on global health governance that the "appropriateness" of re-establishing institutional order by strengthening norms that outline individual responsibilities and competencies of actors with overlapping mandates seems largely uncontested (Holzscheiter, 2015b). This points to a growing desire for centralisation and ordering in this fragmented field of governance by means of streamlining of policies; funding mechanisms; monitoring systems; and through agreements on divisions of labour or the sharing of essential knowledge. As a consequence, an impressive number of global frameworks has been developed in the past decade that seek to create new or strengthen existing arrangements for inter-organisational cooperation-for health and for development assistance overall. In 2010, Balabanova et. al. identified 75 global health partnerships and initiatives whose main purpose was to ensure coordination 
between international actors, as well as between international and domestic actors working on the same issues (Balabanova, McKee, Mills, Walt, \& Haines, 2010). This contrasts with previous tendencies to create an ever greater number of partnerships that addressed new, increasingly specialised substantive issues. Among the new institutional frameworks are five "signed agreements" that continue to be the most important normative frameworks for inter-organisational cooperation in global health governance: the Paris Principles, the International Health Partnership Global Compact, the Three Ones principles (developed specifically for HIV, but then also applied to malaria), the Global Task Team on Improving AIDS Coordination, and the Global Implementation Support Team. As the paper seeks to show in the empirical discussion, these institutions and their underlying normative frameworks can be accounted for as part of a movement of convergence between IOs that is driven by changing norms on good global governance. Yet before elaborating on these empirical observations, the next section outlines our proposed conceptual framework for studying institutional constellations and the influence of reflexive perceptions about "good governance" on the emergence of order amongst IOs.

\section{Explaining Inter-Organisational Convergence in Global Health: The Role of Metagovernance Norms}

Empirical instances of convergence between organisations have come to constitute a blind spot in the current research landscape on inter-organisational relations. Against this backdrop, this paper proposes an alternative conceptual framework for the study of institutional constellations in organisational fields of contemporary global governance. Our framework has two main aspects: first, we develop an empirical-descriptive conceptual toolbox which integrates the study of fragmentation and convergence in inter-organisational relations so as to escape the one-sided focus on fragmentation and ever increasing complexity, which has thus far characterised much scholarly engagement with the topic. Here, we propose to focus on the stabilisation of inter-organisational practices and transformations therein over time. Conceptually, we distinguish between i) fragmentation and convergence as processes which can be observed in interactions between organisations over time, and ii) the concepts of "governance architectures" and "governance hamlets" which we understand to denote more stable institutional constellations that result from the consolidation of such practices. Second, we propose an explanatory framework which highlights the role of metagovernance norms and reflexive governance practices to account for transformations in inter-organisational relations and the emergence of governance architectures. That is, we argue for an analysis of historically grown discursive perceptions about how governance ought to be pursued and their enactments in governance practices to explain convergence between actors, the emergence and (re)organisation of order in organisational fields and the ensuing stabilisation of institutional constellations.

To this end, we combine and develop further existing scholarship on reflexive governance practices, socalled "metagovernance" and recent critical norm theories in IR which conceptualize norms as "enacted meaning-in-use" rather than as fixed containers of meaning (notably, Wiener, 2007, 2014; Wiener \& Puetter, 2009). In a highly innovative paper, David P. Fidler has analysed the metaphor of "architecture" as it has been used in global health, finding that it is being filled with very disparate meanings by different actors and in different contexts (Fidler, 2007). It is such observations that we take as a starting-point in order to argue for the need to study the meaning-struggles revolving around specific notions of inter-organisational order in global health. Such a perspective, we contend, enables one to grasp convergence empirically, but more importantly provides a critical constructivist account of its emergence. Our approach proposes to consider how institutional transformations in global governance are influenced by struggles over interpretation between actors, as well as of how such transformations are tied into and articulated within broader discourses and knowledge domains which define the proper "governance of governance" (Kooiman \& Jentoft, 2009) in a given historical-political context. In other words, the proposed framework combines the study of "power in discourse", by looking at divergent enactments of norms and discursive struggles, with the study of the "power of discourse" in the sense of historically contingent interpretative scripts (Holzscheiter, 2011b, 2014) to explain the emergence of order and institutional transformations in contemporary fields of global governance. To flesh out our concepts and situate them in the literature, we first introduce our empiricaldescriptive conceptual toolbox, then turn to a discussion of our conceptualisation of metagovernance norms and practices and, finally, discuss examples from global health governance which-whilst surely not amounting to a full, systematic application of our framework-serve the purpose of illustrating its possible applications and empirical plausibility.

To avoid setting a predefined focus on dynamics where organisational units, mandates, norms or other entities are seen to "drift apart" or "become more complex", we suggest defining fragmentation and convergence as complementary conceptual antipodes for the study of changing institutional constellations. Importantly, we understand both terms to denote processes that take place in inter-organisational relations over time rather than to describe structural traits of a governance field at any given isolated point in time. 
We define convergence as an increase in the number and depth of cooperative relationships between two or more formally independent organisational units. Correspondingly, we understand fragmentation to designate a decrease in such relationships. On a theoretical level, we support Biermann et. al.'s argument (2009) that all global policy-making can be seen as fragmented and complex albeit to varying degrees. Yet, we challenge the fruitfulness of this insight for empirical analyses of institutional arrangements and inter-organisational relations. Instead we propose to conceptually distinguish between movements of increasing convergence and movements of greater fragmentation between organisational units so that both directions of institutional transformation can be accounted for when studying concrete policy domains. In other words, we seek to go beyond the fixation on mounting "complexity" and omnipresent fragmentation by proposing a research strategy that allows for studying both the emergence of order and its disintegration by tracing patterns of interactions between IOs in the same policy field over time.

To describe more stable, ordered patterns of interaction which crystallize through repetition and institutionalisation in inter-organisational practices over time, we make use of the concept of "governance architecture". While the broader literature on fragmentation and regime complexity widely draws on the metaphor of "architecture" (Biermann et al., 2009; Dias Guerra, Widerberg, Isailovic, \& Pattberg, 2015; Isailovic, Widerberg, \& Pattberg, 2013), we find that it is mostly employed indiscriminately to denote any kind of identifiable institutional structure. ${ }^{4}$ In our theoretical framework, governance architecture refers to the existence of a plurality of synchronised and stable relations between multiple IOs relevant to a policy area or problem. Moreover, we propose the concept "governance hamlets" to describe the opposite condition, namely a lack of such synchronised and stable relations. Finally, whilst we perceive of these concepts as corresponding with empirically observable phenome-

${ }^{4}$ For an exception see Fidler (2007). na, on a conceptual level, we suggest situating them between the ideal-typical concepts "integrated institution" and "atomized governance units" (see Figure 1 below). The latter respectively denote the existence of one single organisational framework within which international governance practices in a given policy area are carried out and the complete absence of such relations. We emphasize that both integrated institutions and atomised governance units are ideal-type extremes that do not exist in global governance: neither is there an international health organisation with an undisputed exclusive mandate that single-handedly carries out all health governance activities on the global level, nor does global health governance consist of free-floating, discrete health IOs that are not tied, at least minimally, to other institutional structures. Figure 1 summarises the described conceptual toolbox.

Beyond conceptualising movements of convergence, fragmentation and ensuing transformations in institutional constellations so that they can be grasped empirically, the question arises how one ought to explain and account for such movements of convergence and fragmentation. As touched upon above, to this end we propose an explanatory framework that draws on theories of metagovernance and critical IR norms theory. That is, we suggest to consider how interorganisational relations in global health governance and other global governance domains are embedded in more encompassing historically grown discourses on the proper "governance of governance" (Jessop, 2014, p. 106) and to pay attention to how actors enact such regularities of speech and thought in reflexive governance practices, thereby (re)producing, (re)ordering and potentially transforming institutional constellations.

In the most generic sense of the term, metagovernance refers to the notion that governance activities which aim at influencing or steering societal processes are themselves governed by second-order governance practices. That is, beyond the "day-to-day" (Kooiman \& Jentoft, 2009, p. 822) governance of society, metagovernance refers to the "governance of governance

\begin{tabular}{|c|c|c|c|c|}
\hline Process & Converging & & & Fragmenting \\
\hline $\begin{array}{l}\text { Institutional } \\
\text { constellations in } \\
\text { policy field and their } \\
\text { properties }\end{array}$ & $\begin{array}{l}\text { Integrated } \\
\text { institution } \\
\text { (ideal type) }\end{array}$ & $\begin{array}{l}\text { Governance } \\
\text { architectures }\end{array}$ & $\begin{array}{l}\text { Governance } \\
\text { hamlets }\end{array}$ & $\begin{array}{l}\text { Atomized } \\
\text { governance units } \\
\text { (ideal type) }\end{array}$ \\
\hline
\end{tabular}

Figure 1. Graphical depiction of conceptual framework. 
itself (Jessop, 2014, p. 106; Torfing, Peters, Pierre, \& Sørensen, 2012). Whilst competing notions of metagovernance exist that will not be elaborated here in any greater detail, for the sake of clarity it is important to stress that we use metagovernance as an open analytical concept which serves to denote a reflexive quality of governance practices and discourses forming around them. Extant scholarly understandings of the term have ranged from such analytical conceptualisations to more empirical-descriptive ones. To exemplify the latter category, in Cologne School theorizing (Mayntz, 1999; Mayntz \& Scharpf, 1995; Scharpf, 2007), integration theory (Kickert \& Koppenjan, 1997; Rhodes, 1996, 1997), Luhmann-inspired scholarship (Braun, 1993; Luhmann, 1984), but also in more recent theoretical accounts of democratic governance (Torfing et al., 2012; Torfing \& Sørensen, 2007), metagovernance tends to be understood as a novel, postmodern kind of governance which aims at steering and/or operates through horizontal networks and independent societal subsystems. Consequently, it is often typologically juxtaposed to other governance modes such as hierarchical coordination (state) and market exchange. In conceptualising metagovernance as a second-order, reflexive form of governance we instead side with the open analytical pole on this theoretical spectrum. From such a viewpoint, metagovernance might be concerned with state/hierarchy, market, networks or indeed with other governance practices, but is ultimately defined by its reflexive quality: by aiming to redesign governance in a self-referential manner. To exemplify this kind of conceptualization, it is worthwhile to consider Bob Jessop's theoretical approach.

Following Jessop, first-order governance denotes non-reflexive activities aimed at directing societal spheres through different "forms of coordination", namely imperative organisation, heterarchy, exchange and solidarity (Jessop, 2014, p. 112). Metagovernance, in turn, refers to governance practices which (re)define the operation of first-order governance modes ("firstorder metagovernance") or their relative importance in governing any given societal realm ("second-order metagovernance", Jessop, 2014, pp. 112-116). In other words, in Jessop's terminology, first-level metagovernance refers to the reflexive redesign of markets, authority structures, self-organisation and bases for solidarity- "loyalty, trust, and commitment" (Jessop, 2014, pp. 114-115), whilst second-order metagovernance denotes "the asymmetrical privileging of different modes of coordination" (Jessop, 2014, p. 116). As a further example, Jan Kooiman and Svein Jentoft advance an understanding of metagovernance that is similarly premised on a distinction between levels of reflexivity in defining it as an "order where values, norms and principles are advanced according to which governance practices can be formed and evaluated" (Kooiman \& Jentoft, 2009, p. 823). Finally, Andrew Dunsire's pro- posal to use the term "collibration" to describe the "manipulation of balancing social tensions, the controlled shifting of a social equilibrium, the fine tuning of an oscillation of near-equal forces" (Dunsire, 1993, p. 11) constitutes a related concept as it is concerned with activities that "set the frame" within which everyday practices of governance take their course.

For the study of inter-organisational relations in realms of global governance, adopting a perspective which is informed by a thus defined understanding of metagovernance therefore sharpens our gaze for common activities and practices between organisations which define and reshape the framework within which governance takes place-such as the creation of new venues for coordination amongst institutions or the reordering of relationships between existing mechanisms and arenas. To exemplify, in the realm of global health governance, we argue that this theoretical lens renders visible the reflexive, ordering quality of a range of initiatives and practices amongst institutions which have emerged since the late 1990s. The International Health Partnership (IHP+; and related initiatives) that was established in 2007, for example, has become a widely accepted harmonisation mechanism for multilateral and bilateral development cooperation for health. It provides for Compacts between donors and recipients at the domestic level, which constitute negotiated agreements between governments and development partners with the aim to reduce donor fragmentation, harmonise donor action and improve alignment with the national health system. The number of these Compacts has grown continuously over the years (Holzscheiter, 2011a; Shorten, Taylor, Spicer, MounierJack, \& McCoy, 2012) which points to the increasing institutionalisation of the partnership as a mechanism to order the relationships between multiple organisations (Buse, 2004; Buse \& Walt, 2002). In Jessop's terminology, the establishment of such harmonisation mechanisms can be analytically described as practices which combine elements of metaheterarchy between IOs, e.g. the reordering of relations in a network-like structure, and elements of metaorganisation, as the more specific agreements between donors, recipient and development partners inevitably address and hence might "tilt" the balance of relative authority between the said actors in the respective area of concern. Another example for such harmonising initiatives was the "H4+" Partnership which-until 2016-constituted an inter-organisational structure holding together six United Nations (UN) organisations (UNAIDS, UNFPA, UNICEF, United Nations Entity for Gender Equality and the Empowerment of Women [UN Women], WHO and the World Bank). This group of $\mathrm{H} 4+$ acted as the lead technical partner for the implementation of the UN Global Strategy for Women's and Children's Health and as a central implementation mechanism for Millennium Development Goals 4 (Child Health) and 5 (Maternal 
Health). As these kinds of reflexive, ordering practices increase in numbers, stabilise and consolidate over time, they unfold a transformative effect on the institutional constellation in the field as a whole. In other words, the emergence and proliferation of metagovernance can be seen to change the functioning and nature of global health governance in the aggregate, as despite the continuing plurality of actors, their interactions amongst each other increasingly follow more stable, sedimented paths. This kind of emergent order in inter-organisational relations is what we propose to describe as an emerging "governance architecture".

Now, if the transformation of institutional constellations and emergence of order in global governance policy realms might be accounted for by considering how reflexive governance practices stabilise over time, a crucial question has still been left unaddressed. To stick to the empirical realm of global health governance, why did IOs in the historical institutional setting just discussed perceive of a need to "harmonise" and "coordinate" their activities, rather than to pursue any alternative course of action, using other words and engaging in other activities? How, more specifically, did the overarching rhetorical commitment to the principle of harmonisation translate into tangible practices and how would some of them come to gradually acquire a higher level of stability and institutionalisation? As touched upon earlier, in order to uncover the specificity and explain the diachronic stabilisation of emergent orders in inter-organisational fields, we propose to draw on recent theoretical proposals in critical IR norms research. Norms research continues to be a popular field of scholarly inquiry in the field of IR and it has made significant advances with regard to explaining how norms emerge, unfold and transform. Early norms research predominantly pursued the quest to identify norms in international politics, to explain why they emerge and under what conditions they diffuse (actors; opportunity structures; hegemonic actors; issue characteristics) (Colonomos, 2001; Finnemore \& Sikkink, 1998; Keck \& Sikkink, 1998; Nadelmann, 1990; Price, 1998; Risse, 2002). Newer research on norms has shifted emphasis to observing and explaining what happens to international norms in the long run, how they transform, translate into different contexts and also how their meaning and effects are contingent on (re)production in practice (Grillot, 2011; Krook \& True, 2012; Wiener, 2009; Zwingel, 2012). The idea that norms structure social life while at the same time being contested and loaded with controversies is a central tenet of contemporary critical norms research. Our ambition to trace the institutional evolution in global health ties in with this second wave of norms research inasmuch as we embrace the assumption that norms simultaneously have a structuring and contingent quality. To study the existence and effects of metagovernance norms in global health through discourses on good global health governance is thus, in our view, a necessary endeavour with regard to identifying both periods of normative stability and periods of movement and transformation.

In contrast to the rationalist institutionalist mainstream which has so far dominated the engagement with inter-organisational relations in the field of IR research (Jönsson, 1986; Koops \& Varwick, 2009) we thus propose a constructivist account of how metagovernance practices emerge and unfold. That is, we suggest that the reflexive reordering and redesigning of governance itself-which the concept of metagovernance enables us to highlight-is embedded, enacted and reproduced in broader historically grown discourses about the appropriate "governance of governance". Drawing on Antje Wiener's account of norms as "enacted meaning-in-use" (Wiener, 2009) we conceptualize metagovernance norms as contingent perceptions about how governance ought to be pursued that are enacted and negotiated in social practices (cf. also Wiener, 2007; Wiener \& Puetter, 2009). If we understand the term discourse as a more encompassing concept which refers to an overarching regularity or formation of perceptions/knowledge and practices that delineate the borders of what is reasonably thinkable in a given socio-political context (cf. Foucault, 1972), metagovernance norms can be described as a category of discursive objects which emerge as parts of such discourses to establish moral, ethical imperatives (what is believed to be "good") and are closely interwoven with causal beliefs (what is believed to be "necessary" and "possible") about how governance ought to be pursued and organised. Conceptualising metagovernance norms as a category of discursive objects, rather than as fixed normative entities or stable "standards of appropriate behavior for actors within a given identity" (Katzenstein, 1996, p. 5) has important consequences for their analysis. First, if discourse is historically contingent and reproduced in social practices, the meaning of norms is principally open to divergent and indeed conflicting interpretations amongst actors in the same field. Or, to reformulate this point by borrowing a phrase from Wiener, as "the rule always lies in the practice...norms-and their meanings [are] contested by default" (Wiener, 2007, p. 5). Second, such a perspective underlines the necessity to consider how the power of norms is underpinned by and made possible through the discursive context in which they emerge; to inquire into their relationship with other discursive objects, causal beliefs and knowledge domains. Both of these points, finally, should encourage us to engage with the delicate relationship between norms and power by addressing how, on the one hand, power is exerted by actors in discourse through struggles about the meaning of norms, as well as how, on the other hand, the power of discourse restricts the realm of reasonably speakable statements - the political and factu- 
al imaginary-within which actors struggle, rearticulate and enact norms about how to govern. Let us once again turn to the example of global health governance to illustrate what these theoretical considerations might imply for empirical research.

\section{Shifting Discourses and Norms of Good Global Health Governance}

We are certainly not the first to explore the contestation revolving around the notion of "global health governance" in terms of what it means, which actors it includes and where its boundaries are (Cooper, Kirton, \& Schrecker, 2007; Fidler, 2007; Hein, Bartsch, \& Kohlmorgen, 2007; Lee \& Kamradt-Scott, 2014). However, we seek to advance this debate by proposing to study inter-organisational practices and the meanings enacted therein across time. Such a focus, we suggest, delivers important insights into the normative underpinnings of global health and promises to shed light on how meaning-struggles transform and give rise to distinct patterns of interaction between organisations. To study discourses on "good global health governance" as they evolve among health organisations themselves, thus, is necessary in order to uncover the procedural norms that have structured and ordered inter-organisational interactions at specific points in time. In other words, we believe that our perspective represents an innovative take on the subject by making visible how interorganisational interactions in global health governance are being structured by metagovernance norms while, at the same time, enabling us to consider how such norms are continuously (re)negotiated. To illustrate this point, the strong negative connotation that is routinely attached to the terms "fragmentation" and "complexity" can be identified as a textual representation of a powerful, overarching belief that unites the world of science and the world of practice in global health. Social Science and Public Health research on global health have been largely dominated by rationalist-functionalist institutionalist theory in which the existence of overlapping or even competing rule-systems and organisational mandates is mostly perceived as a dysfunctional feature of regime complexes and associated with high transaction costs. These transaction costs are often related to the duplication of management structures targeting the same issue or problem; the duplication of operational activities in the field; incongruent indicators for monitoring policy issues; or the co-existence of different and often contradictory rule-systems that states (and other actors) should comply with domestically. The formula "coordination/harmonisation = more effectiveness" has emerged as almost a truism or at least a strong causal belief about what constitutes "good governance" in communities of scholars and practitioners alike. Harmonisation of this orchestra of global health-which is not only perceived to be many-piece but also dissonantemerges as a normatively desirable solution that promises to cure problems of ineffectiveness and inefficiency. The following section provides examples from different discourses on global health and demonstrates that this turn towards "harmonisation" constitutes a significant change in metagovernance norms, reflected not only in the rhetorical commitment of all major international health agencies to harmonisation as a metagovernance principle-but more importantly in the many interactions that health IOs have undertaken to translate these principles into practice.

\subsection{Early Periods of Global Health Governance: 1940s-1970s and 1970s-2000s}

International cooperation in health matters dates back to the mid-19 $9^{\text {th }}$ century when the first International Sanitary Conference was convened in response to a series of worrying cholera outbreaks in Europe. WHO, that was established in 1948, owes its historical legacy to two predecessors: the International Sanitary Bureau established in 1902 in Washington (later named the Pan-American Sanitary Bureau) and the Office International d'Hygiène Publique (OIHP) established in Paris in 1907 (Fidler, 1997, 1999, 2001; Goodman, 1977). However, the international institutional structures propping up the issue of health were built after 1945, originating in the WHO with a much broader and truly "international" mandate than earlier organisations as well as more specialised IOs with health-related tasks such as the International Labour Organization (ILO), UNICEF or the World Bank. For this reason, our account of interorganisational cooperation in global health governance starts in the late 1940s. Most of the health-related IOs that were established after the Second World War centred on the promotion of health as an instrument for economic development and overall progress. Health became "a tool for enabling the full utilization of human capital" (Inoue \& Drori, 2006, p. 209). In the early period of international organisation in the field of health (1940-1970), thus, classical state-centred international politics and a global health policy field revolving around WHO conjured up an image of health governance as based on a relatively straightforward division of labour between the latter organisation and national governments or their ministries of health. This organisation of governance points towards metaorganisation as a prevalent type of second-order governance in which WHO constituted the undisputed focal-point for all other actors in the "health universe".

The 1970 s and 1980s constituted the beginning of "unsettled periods" (Swidler, 1986, p. 273) in global health, as during these decades discourses on health were changing and new powerful agencies entered the arena. On the one hand, thinking on international/global health policymaking was influenced by trends 
associated with the "Health for All"-movement and the movement for a "New Economic Order" within the United Nations. Some aspects of this intellectual current included the framing of health as a right and the insistence that health policy should be holistic and focus on health systems (Lidén, 2013, pp. 14-15). This early infusion of the field of health policy with discourses on human rights, equity and social justice, initiated a growing politicisation of WHO under its Secretary-General Halfdan Mahler (1973-1988) which, in turn, led to an increasing estrangement of WHO from some of its Member States. At the same time, the 1970s also saw the rise of further, competing perceptions which associated "good governance" in the realm of global health with policies underpinned by a view of health as a factor in achieving economic development and poverty reduction. According to some commentators, the World Bank was instrumental in transmitting this "health and development"-discourse which had been formulated and constructed in academia (Ruger, 2005 ) into the field of global health policy in the 1970s. As one author notes, the Bank "has persuasively argued that alleviating global poverty and achieving broad-based development requires healthy people. III health puts a drain on a state's resources, and unhealthy people cannot contribute to a country's economic development" (Youde, 2012, p. 46). The World Bank introduced quantification of (expected) policy outcomes as a measure to determine where policy "interventions" would be most efficient. Following some authors, this stood in contrast to the emphasis of WHO on strengthening health systems. The Bank's 1993 World Development Report entitled "Investing in Health" made sweeping, yet influential recommendations in this regard: It pushed the notion of efficiency in health policy and national health systems in pursuit of the larger aim of poverty reduction, e.g., by calling for private sector involvement, and introduced quantifiable measures to assess the burden of diseases (especially Disability-Adjusted Life Years-DALYs) (Ruger, 2005, p. 66). The conception of health entailed therein was widely perceived as contradicting that of WHO (Davies 2010: 45-6 as cited in Youde, 2012, p. 51). Deciding on health "interventions" on the basis of quantitative indicators of efficiency became the new standard in the field of global health. This could in part be attributed to the influence of the World Bank that is grounded in its lending power, but can also be seen as a reflection of broader discursive shifts towards linking "good governance" to economic efficiency and the neoliberal Zeitgeist of the 1990s that presented privatisation and quantification as more efficient alternatives to the way global health had previously been governed.

A closer look at the Global Burden of Disease and Disease Control Priorities Project allows us to trace some of the mentioned changes in health governance. The Global Burden of Disease-approach refers to the attempt to quantify the burden of specific diseases in order to inform policy-making. Results of this project were first included in the abovementioned 1993 World Development Report. The project was initially housed at WHO, which formalized its work through a Disease Burden Unit in 1998 and has published its updated results over the years (Institute for Health Metrics and Evaluation, 2015). The updated report of 2010, however, received funding from the Bill \& Melinda Gates Foundation and was put together by the World Bank, WHO and the Fogarty International Center of the U.S. National Institutes of Health (Jamison et al., 2010 front matter). Today, coordination of updates to the report has moved to the Institute for Health Metrics and Evaluation, which was co-founded by the Gates Foundation. The Global Burden of Disease Project could be interpreted as an institutional embodiment of the rise of effectiveness and numerical indicators and "health interventions" to combat specific diseases, in contrast to approaches to health governance that favour health systems strengthening. It also points to the increasing participation of non-state actors in the governance of global health, with the gradual move of the project away from "traditional" health IOs.

This trend equally affected other IOs. As new global health organisations were founded after 1990 (e.g., UNAIDS, Global Fund), their mandates came to reflect a perceived necessity to open up IOs to increased collaboration with other health actors, particularly with non-governmental organisations (Holzscheiter, 2015b, p. 8). To illustrate further, consider the Multi-Country HIV/AIDS Program (MAP) that was founded by the World Bank in 2000 as "a central, prominent lending program" (Youde, 2012, p. 56) to combat HIV/AIDS. It seems remarkable how much this programme sought to avoid working with state actors as it explicitly required receiving states to disburse significant portions of the funds to non-state actors, including "civil society organizations, national nongovernmental organizations, and community groups" (Youde, 2012, p. 56). We thus broadly see that over time cooperation in health governance changed from inter-agency partnerships usually sustained by WHO, the World Bank and others to so-called "innovative" partnerships that accorded a more significant role to non-state actors. The discourses on "innovation" and "partnership" were accompanied by an increasing number of private actors as funders and partners in health governance, the highlighting of quantitative evidence as the basis for policy decisions ("health interventions") and the evaluation of their effectiveness, as well as the desire to use "market-based" mechanisms to fund research and the development of vaccines. In sum, the discussed transformations in global health governance from the 1970s to early 2000s therefore point to how metagovernance norms, about the desirability of privatisation of governance and pluralisation of actors, together 
with causal beliefs produced in scholarly discourse which underpin such perceptions (e.g. evidence that market based-mechanisms produce more "efficient" results) might translate into second-order metagovernance practices that change the relative importance of imperative coordination, heterarchy and exchange-in this case to the advantage of the latter two forms of coordination.

\subsection{Global Health Governance after the Turn of the Millennium: 2000s-Present}

In contrast to the "health and development"-discourse and the associated metagovernance norms about "privatisation", "pluralisation" and "policy innovation", discourses forming around terms such as "coordination", "harmonisation" and "partnership" took centre stage in the 2000s. The call for harmonisation has become ubiquitous across all current major global health issues (Holzscheiter, 2015b, p. 3). Not least through the harmonisation principle contained in the 2005 Paris Declaration on Aid Effectiveness has this norm made its way from development cooperation to health governance (Organisation for Economic Co-operation and Development, 2005). For example, the Three Ones Principles were adopted around the same time with the explicit aim to harmonise action by multilateral and bilateral donors addressing HIV/ AIDS through One National AIDS Strategy, One National Monitoring \& Evaluation System and One National AIDS Authority (The Joint United Nations Programme on HIV and AIDS, 2004). The Paris Declaration and the Three Ones Principles have unfolded their converging effect on the field of global health governance. The Global Fund, the World Bank and the UN family more generally have been most active in this regard (Holzscheiter, 2015b, p. 14). Particularly the Paris Principles are reflected in the organisational philosophies and strategies of all important health IOs (Holzscheiter, 2015b, p. 14). Beyond statements on paper, health IOs have built forums through which they seek to harmonise their activities, including IHP+ and the $\mathrm{H} 4+$ partnership. They bring and brought together staff of different IOs in temporary expert and working groups that are jointly hosted by these IOs (Holzscheiter, 2015b, pp. 14-15). To illustrate, consider IHP+, which is hosted by WHO and the World Bank to "enhance aid effectiveness...through effective collaboration and coordination of various partnerships and initiatives" (World Health Organization/World Health Assembly, 2010, p. 2). The changes that the Paris Declaration has induced in health IOs' policies and practices testifies to the effect of the harmonisation norm that has unfolded in the health policy field as a whole. Harmonisation and coordination have become synonymous with "better" health governance, i.e., health governance that is viewed as more legitimate and effective (President's Emergency Plan for AIDS Re- lief, 2007; The Global Fund to Fight AIDS, Tuberculosis and Malaria, 2010; cf. The Joint United Nations Programme on HIV and AIDS, 2006). In contemporary discourses on "good governance" in global health, harmonisation and coordination constitute broadly accepted-indeed even largely unchallenged-principles (Holzscheiter, 2015a). They can hence be described as powerful metagovernance norms which are underpinned by discursive perceptions and regularities positing their necessity and desirability, such as the frequently occurring opposition to "fragmentation" in scholarly discourse and the discussed negative connotation of this term.

However, the more precise meaning of the term "harmonisation" and in particular the practical consequences for the organisation of governance that it is seen to entail, are far from undisputed. In other words, whilst the desirability of harmonisation as such is currently uncontested, its exact meaning is more unstable and hence the object of struggle between competing interpretations and enactments. On the one hand, some attempts at fixating the meaning of harmonisation understand it as requiring a coherence of action by diverse health IOs, as was illustrated in the foregoing examples of IHP+ and $\mathrm{H} 4+$. On the other hand, other actors envision harmonisation as entailing a division of labour between health IOs in which roles are divided on the basis of specialised functions and comparative advantages (The Joint United Nations Programme on HIV and AIDS Lancet Commission, 2013). To exemplify, the latter version of the harmonisation norm was embodied in a 2014 partnership agreement between the Global Fund and WHO which spells out their division of labour in the field. The agreement envisages that WHO should support countries seeking funds from the Global Fund with technical assistance (World Health Organization, 2014). In a similar vein, the Global Fund has also spelled out its relationship with UNAIDS and UNICEF, amongst other UN organisations (The Global Fund to Fight AIDS, Tuberculosis and Malaria, 2009). The former agreement shows that WHO has managed to reassert its authority in this particular relationship by translating a specific interpretation of the harmonisation norm into inter-organisational, reflexive practices and hence illustrates that IOs actively seek to seize metagovernance norms to stake out their spheres of authority (cf. Holzscheiter, 2015b, pp. 16-17).

The field of global health governance provides further examples of convergence through a division of labour: around 2000, with the adoption of the Millennium Declaration and the Millennium Development Goals and with immense frustration regarding the AIDS epidemic and other infectious diseases, a whole series of vertical health partnerships were established. Among the most prominent of these partnerships were the Roll Back Malaria Initiative (1998), the Stop TB Partnership (2000) and Gavi (2000). These 
partnerships were explicitly designed as institutions aiming at metaheterarchy and metaexchange, i.e. reflexive, voluntary and horizontal forms of cooperation which sought to reorder networks of health actors and related markets (for access to medicines, research \& development, health personnel, etc.). Many of these partnerships-such as Stop TB or Roll Back Malariaare so-called "hosted" partnerships, which means that their secretariats are located at WHO, UNICEF or other UN organisations and are thus not free-standing legal entities. Others, such as Gavi, were set up as organisations operating in the geographical vicinity of, but independently from, UN organisations. Following a decision of the WHO Executive Board in 2013 and a protracted debate on the legal status of these hosted partnerships, serval memoranda of understanding were set up that either aim at re-establishing WHO's authority over the partnerships or seek to clarify the division of labour between the organisation and the partnerships by delineating their respective "spheres of authority". ${ }^{5}$ In that instance, we thus witness a movement of convergence in the field of global health that is driven by the reflexive reorganisation of authority structures: after the period of "policy innovation", "pluralization" and "privatisation" in the 1990s and early 2000s that saw the founding of new health IOs and novel kinds of initiatives, such as the Roll Back Malaria Initiative, Gavi and the Global Fund, more recent global health governance is characterised by an opposite movement in patterns of interaction between organisations towards a partial return to the leading role of WHO and thus towards privileging imperative coordination as well as noticeable efforts by IOs to clarify and divide roles. Even those organisations and partnerships that emerged in the wake of the innovation and partnership discourses have felt compelled to clarify how they relate to their older peers that were once dismissed as relics of ineffective, hierarchical bureaucracy and have sometimes-as was shown above in the case of the Global Fund-deferred to their pedigree in the name of harmonisation and effectiveness. To conclude, it appears that a rationalist-functionalist perspective on global health governance that focuses exclusively on the increase in actors and rules lends itself to the hasty conclusion that this policy field is inevitably messy, while a closer analysis can reveal stabilising relationships and historically changing, discursively embedded instances of metagovernance that reflexively rearrange the parameters within which health IOs interact and operate.

\section{Conclusions}

Embarking from a critique of the one-sided focus on the bewilderingly "complex" aspects of fragmentation

${ }^{5}$ See for example Memorandum of Understanding between the Roll Back Malaria Partnership and WHO (2006). and complexity in contemporary global governance scholarship, the bulk of the present paper has presented an alternative framework for the analysis of interorganisational relations in global governance fields. More specifically, we have argued for an historical perspective that conceives of convergence and fragmentation as opposite, mirroring patterns of interaction between organisations. As they evolve over the course of time, they give rise to governance constellations of varying density; in our proposed terminology these could range from "governance architectures" to "governance hamlets" (see above pp. 6-7). In order to account for such transformations, we sketched out an explanatory framework that draws on theories of metagovernance and critical IR norms theory in suggesting that inter-organisational practices are driven by, or rather can be seen to constitute enactments of, discursive perceptions about the proper "governance of governance". In contrast to the rationalistfunctionalist institutionalisms that have so far dominated much of the social science engagement with global (health) governance, we propose a constructivist approach that distinguishes between different levels of reflexivity to explain emergent orders in global governance. The empirical examples and indications given in this paper are a first step towards a more systematic analysis of both discourses and practices of metagovernance in global health governance. However, the above empirical analysis clearly indicates that interorganisational patterns of interaction are embedded in and informed by broader discourses on how one can and ought to govern. As we show above, dominant perceptions about what constitutes "good governance of governance" in the health realm are distinctly historically contingent: For the past few decades they have ranged from rights-based understandings connected to visions of a more equitable "New Economic Order", to discourses that locate global health governance within frames of quantitative economic output and development, innovation and marketisation. Moreover, in many of these instances, causal beliefs and implicit normative connotations transcend the borders between the practice of global health governance and scholarly engagement therewith. For instance, an overarching negative connotation of the terms "fragmentation" and "complexity" has crystallized in both realms through the last decade, often assuming the function of causal background knowledge that makes it possible for "harmonization" to figure as a logical, common sense solution to ineffectiveness and inefficiency. Yet, as the above diachronic tracing of interorganisational interactions, institutional developments and their discursive embeddedness also points to, the more precise meaning of dominant metagovernance norms and hence their translation into practice, far from being a technical matter, constitutes a continuous object of contestation. As we illustrate above, in the 
case of harmonization, struggles have erupted between enactments that interpret the norm as suggesting a stronger centralization of governance processes or in other words a move towards hierarchy, and others that posit the meaning of the norm as a greater functional division of labour between 10 actors along lines of comparative advantage. To conclude, studying institutional constellations as a product of historical processes of discursive struggle and stabilisation sharpens our gaze for their contingent, non-technical and hence political origins. Moreover, this gives reason to reconsider the undisputed focus on enhancing effectiveness of pre-existing governance arrangements that has determined the course of much research on global governance.

\section{Acknowledgments}

The Junior Research Group Governance for Global Health is jointly funded by Freie Universität Berlin within the German Research Foundation's (DFG) Excellence Initiative and WZB Berlin Social Science Center. The publication of this article was funded by the Open Access fund of the Leibniz Association. The authors wish to thank Sibylle Kranwetvogel for excellent research assistance.

\section{Conflict of Interests}

The authors declare no conflict of interests.

\section{References}

Balabanova, D., McKee, M., Mills, A., Walt, G., \& Haines, A. (2010). What can global health institutions do to help strengthen health systems in low income countries? Health Research Policy and Systems, 8(1), 1-11. doi:10.1186/1478-4505-8-22

Biermann, F., Pattberg, P., van Asselt, H., \& Zelli, F. (2009). The fragmentation of global governance architectures: A framework for analysis. Global Environmental Politics, 9(4), 14-40. doi:10.1162/glep. 2009.9.4.14

Braun, D. (1993). Zur Steuerbarkeit funktionaler Teilsysteme: Akteurtheoretische Sichtweisen funktionaler Differenzierung moderner Gesellschaften. Politische Vierteljahresschrift, 24, 199-222.

Buse, K. (2004). Governing public-private infectious disease partnerships. Brown Journal of World Affairs, 10(2), 225-242.

Buse, K., \& Walt, G. (2002). Globalisation and multilateral public-private health partnerships: Issues for health policy. In K. Lee, K. Buse, \& S. Fustukian (Eds.), Health policy in a globalizing world (pp. 41-62). Cambridge: Cambridge University Press.

Cerny, P. G. (2010). Rethinking world politics. Oxford: Oxford University Press.
Colonomos, A. (2001). Non-state actors as moral entrepreneurs: A transnational perspective on ethics networks. In D. Josselin \& W. Wallace (Eds.), Non-state actors in world politics (pp. 76-89). London: Palgrave.

Cooper, A. F., Kirton, J. J., \& Schrecker, T. (Eds.). (2007). Governing global health: Challenge, response, innovation. Farnham, UK: Ashgate.

Dias Guerra, F., Widerberg, O., Isailovic, M., \& Pattberg, P. (2015). Mapping the institutional architecture of global climate change governance (Technical Report R-15/04). Amsterdam: IVM Institute for Environmental Studies.

Drezner, D. W. (2007). All politics is global. Cambridge: Cambridge University Press.

Dunsire, A. (1993). Manipulating social tensions: Collibration as an alternative mode of government intervention (MPIFG Discussion Paper 93/7). Cologne, Germany: Max-Planck-Institut für Gesellschaftsforschung.

Fidler, D. P. (1997). The globalization of public health: Emerging infectious diseases and international relations. Indiana Journal of Global Legal Studies, 5(1), 11-51.

Fidler, D. P. (1999). International law and infectious diseases. Oxford: Clarendon Press.

Fidler, D. P. (2001). The globalization of public health: The first 100 years of international health diplomacy. Bulletin of the World Health Organization, 79(9), 842849.

Fidler, D. P. (2007). Architecture amidst anarchy: Global health's quest for governance. Global Health Governance, 1(1).

Finnemore, M., \& Sikkink, K. (1998). International norm dynamics and political change. International Organization, 52(4), 887-917. doi:10.1162/0020818985507 89

Foucault, M. (1972). The archeology of knowledge \& the discourse on language. London: Tavistock.

The Global Fund to Fight Aids, Tuberculosis and Malaria. (2009). The Global Fund's partnership strategy. Geneva, Switzerland: GFATM.

The Global Fund to Fight Aids, Tuberculosis and Malaria. (2010). Improving effectiveness. Information note. Geneva, Switzerland: GFATM.

Godal, T. (2005). Opinion: Do we have the architecture for health aid right? Increasing global aid effectiveness. Nat Rev Microbiol, 3(11), 899-903.

Goodman, N. M. (1977). International health organizations and their work. London: Churchill Livingstone.

Government of Namibia. (2010). UNGASS country report 2008-2009. Windhoek, Namibia: Government of Namibia, Ministry of Health and Social Services.

Grillot, S. R. (2011). Global gun control: Examining the consequences of competing international norms. Global Governance, 17(4), 529-555.

Hein, W., Bartsch, S., \& Kohlmorgen, L. (Eds.). (2007). Global Health governance and the fight against 
HIV/AIDS. London: Palgrave Macmillan.

Holzscheiter, A. (2010). Children's rights in international politics. The transformative power of discourse. Basingstoke: Palgrave Macmillan.

Holzscheiter, A. (2011a). International health partnership and IHP+. In T. Hale \& D. Held (Eds.), Handbook of transnational governance. Institutions \& innovations (pp. 189-194). London: Polity Press.

Holzscheiter, A. (2011b). Power of discourse or discourse of the powerful? The reconstruction of global childhood norms in the drafting of the UN Convention on the Rights of the Child. Journal of Language and Politics, 10(1), 1-28.

Holzscheiter, A. (2014). Between communicative interaction and structures of signification: Discourse theory and analysis in international relations. International Studies Perspectives, 15(2), 142-162. doi:10.1111/insp.12005

Holzscheiter, A. (2015a). Interorganisationale Harmonisierung als sine qua non für die Effektivität von Global Governance? Eine soziologischinstitutionalistische Analyse interorganisationaler Strukturen in der globalen Gesundheitspolitik. In E. de Conceicao-Heldt, M. Koch, \& A. Liese (Eds.), Politische Vierteljahresschrift Sonderheft 49 (pp. 322-348). Baden-Baden, Germany: Nomos.

Holzscheiter, A. (2015b). Restoring order in global health governance. CES open forum series. Cambridge, MA: Center for European Studies, Harvard University.

Holzscheiter, A., Walt, G., \& Brugha, R. (2012). Monitoring and evaluation in global HIV/AIDS controlWeighing incentives and disincentives for coordination among global and local actors. Journal of International Development, 24(1), 61-76.

Huckel, C. (2005, August). Global public health governance: Who develops policy? Paper presented at the Global International Studies Conference, Bilgi University, Istanbul, Turkey.

Hülsemeyer, A. (Ed.). (2003). Globalization in the twentyfirst century: Convergence or divergence? Basingstoke: Palgrave Macmillan.

Inoue, K., \& Drori, G. S. (2006). The global institutionalization of health as a social concern: Organizational and discursive trends. International Sociology, 21(2), 199-219. doi:10.1177/0268580906061376

Institute for Health Metrics and Evaluation. (2015). GBD history. Institute for Health Metrics and Evaluation. Retrieved from http://www.healthdata.org/gbd/about/ history

International Development Association. (2007). Aid architecture: An overview of the main trends in official development assistance. Washington D.C.: International Development Association.

Isailovic, M., Widerberg, O., \& Pattberg, P. (2013). Fragmentation of global environmental governance architectures: A literature review (Vol. W-13/09).
Amsterdam: IVM Institute for Environmental Studies. Jamison, D. T., Breman, J. G., Measham, A. R., Alleyne, G., Claeson, M., Evans, D. B., . . Musgrove, P. (2010). Disease Control priorities in developing countries. New York: The World Bank and Oxford University Press.

Jessop, B. (2014). Metagovernance. In M. Bevir (Ed.), The SAGE handbook of governance (pp. 106-123). London: SAGE Publications.

Jönsson, C. (1986). Interorganization theory and international organization. International Studies Quarterly, 30, 39-57.

Karns, M. P., \& Mingst, K. A. (2004). International organizations: The politics and processes of global governance. Boulder, CO: Lynne Rienner Publishers.

Katzenstein, P. J. (1996). Cultural norms and national security. Policy and military in postwar Japan. Ithaca and London: Cornell University Press.

Keck, M., \& Sikkink, K. (1998). Activists beyond borders: Advocacy networks in international politics. Ithaca: Cornell University Press.

Kickert, W., \& Koppenjan, J. (1997). Public Management and network management: An overview. In W. Kickert, J. Koppenjan, \& E.-H. Klijn (Eds.), Managing complex networks: Strategies for the public sector (pp. 36-62). London: SAGE Publications.

Kooiman, J., \& Jentoft, S. (2009). Metagovernance: Values, norms and principles, and the making of hard choices Public Administration, 87(4), 818-836.

Koops, J., \& Varwick, J. (2009). The European Union and NATO: Shrewd interorganizationalism in the making? In K. E. Jørgensen (Ed.), The European Union and international organizations. London: Routledge.

Krook, M. L., \& True, J. (2012). Rethinking the life cycles of international norms: The United Nations and the global promotion of gender equality. European Journal of International Relations, 18(1), 103-127. doi:10.1177/1354066110380963

Lee, K., \& Kamradt-Scott, A. (2014). The multiple meanings of global health governance: A call for conceptual clarity. Globalization and health, 10(1), 1.

Lidén, J. (2013). The grand decade for global health: 1998-2008. Centre on global health security working group papers (Working Group on Global Governance, Paper 2). London: Chatham House.

Luhmann, N. (1984). Soziale Systeme: Grundriß einer allgemeinen Theorie. Frankfurt a.M., Germany: Suhrkamp.

Mayntz, R. (1999). Multi-level governance: German federalism and the European Union. In C. Lankowski (Ed.), Governing beyond the nation-state: Global public policy, regionalism or going local? (pp. 100-126). Washington D.C.: American Institute for Contemporary German Studies.

Mayntz, R., \& Scharpf, F. (Eds.). (1995). Gesellschaftliche Selbstregulierung und politische Steuerung. Frankfurt a.M., Germany: Campus Verlag. 
Ministry of Health and Social Services of the Republic of Namibia. (2010). National strategic framework for HIV and AIDS response in Namibia 2010/11 2015/16. Retrieved from http://www.ilo.org/wcmsp 5/groups/public/---ed_protect/---protrav/---ilo_aids/ documents/legaldocument/wcms_301802.pdf

Murray, J. L., \& Dieleman, J. (2014). Global health funding reaches new high as funding priorities shift. Institute for Health Metrics and Evaluation. Retrieved from http://www.healthdata.org/news-release/glob al-health-funding-reaches-new-high-funding-prioritie s-shift

Nadelmann, E. (1990). Global prohibition regimes: The evolution of norms in international society. International Organization, 44(4), 479-526.

National AIDS Council Zambia. (2014). Zambia's national AIDS spending assessment. Retrieved from http:// www.unaids.org/sites/default/files/en/media/unaids /contentassets/documents/data-andanalysis/tools/nasa/20141017/zambia_2012_en.pdf

Organisation for Economic Co-operation and Development. (2005). The Paris declaration on aid effectiveness. Retrieved from https://www.oecd.org/dac/ effectiveness/34428351.pdf

Organisation for Economic Co-operation and Development. (2008). Accra agenda for action. Retrieved from https://www.oecd.org/dac/effectiveness/3442 8351.pdf

Organisation for Economic Co-operation and Development. (2011a). Aid to agriculture and rural development. Retrieved from http://www.oecd.org/dac/ stats/49154108.pdf

Organisation for Economic Co-operation and Development. (2011b). Aid to agriculture and rural development. OECD. Retrieved from www.oecd.org/dac/ aidstatistics/49154108.pdf

Organisation for Economic Co-operation and Development. (2011c). Aid to health. OECD. Retrieved from www.oecd.org/dac/aidstatistics/49907438.pdf

President's Emergency Plan for AIDS Relief. (2007). The power of partnerships: Third annual report to Congress on PEPFAR. Washington D.C.: PEPFAR.

Price, R. (1998). Reversing the gun sights: Transnational civil society targets land mines. International Organization, 5(3), 613-644.

Ravishankar, N., Gubbins, P., Cooley, R. J., Leach-Kemon, K., Michaud, C. M., Jamison, D. T., \& Murray, C. J. (2009). Financing of global health: Tracking development assistance for health from 1990 to 2007. The Lancet, 373(9681), 2113-2124.

Rhodes, R. (1996). The new governance: Governing without government. Political Studies, XLIV, 652-667.

Rhodes, R. (1997). Understanding governance: Policy networks, governance, reflexivity and accountability. Buckingham: Open University Press.

Risse, T. (2002). Transnational actors and world politics. In W. Carlsnaes, T. Risse, \& B. Simmons (Eds.), Hand- book of international relations (pp. 255-274). London: SAGE Publications.

Rosenau, J. N. (2000). Change, complexity, and governance in a globalizing space. In J. Pierre (Ed.), Debating governance. Authority, steering, and democracy (pp. 167-200). Oxford: Oxford University Press.

Rosenau, J. N. (2004). Strong demand, huge supply: Governance in an emerging epoch. In I. Bache \& $\mathrm{M}$. Flinders (Eds.), Multi-level governance (pp. 31-48). Oxford: Oxford University Press.

Ruger, J. P. (2005). The changing role of the World Bank in global health. American Journal of Public Health, 95(1), 60-70. doi:10.2105/AJPH.2004.042002

Scharpf, F. (1994). Games real actors could play: Positive and negative co-ordination in embedded negotiations. Journal of Theoretical Politics, 6(1), 27-53.

Scharpf, F. (2007). Notes toward a theory of multilevel governing in Europe (MPIfG Discussion Paper, Vol. 00/5). Cologne, Germany: Max-Planck-Institut für Gesellschaftsforschung.

Schieber, G. J., Gottret, P., Fleisher, L. K., \& Leive, A. A. (2007). Financing global health: Mission unaccomplished: Better-quality aid and more coordination among donor and recipient countries are critical to improving aid effectiveness. Health Affairs, 26(4), 921-934.

Shaffer, G. (2005). Power, governance, and the WTO: A comparative institutional approach. In M. N. Barnett \& R. Duvall (Eds.), Power in global governance (pp. 130-160). Cambridge: Cambridge University Press.

Shorten, T., Taylor, M., Spicer, N., Mounier-Jack, S., \& McCoy, D. (2012). The International health partnership plus: Rhetoric or real change? Results of a selfreported survey in the context of the 4th high level forum on aid effectiveness in Busan. Globalization and health, 8(13), 1-13.

Sidibé, M., Tanaka, S., \& Buse, K. (2010). People, passion \& politics: Looking back and moving forward in the governance of the AIDS response. Global Health, 4(1).

Smith, R. (1995). The WHO: Change or die. BMJ, 310(6979), 543-544.

Swidler, A. (1986). Culture in action: Symbols and strategies. American Sociological Review, 51(2), 273-286.

Taylor, A. L. (2002). Global governance, international health law and WHO: Looking towards the future. Bulletin of the World Health Organization, 80(12), 975-980.

The Joint United Nations Programme on HIV and AIDS. (2004). Three ones: Key principles. Geneva, Switzerland: UNAIDS.

The Joint United Nations Programme on HIV and AIDS. (2006). UNAIDS annual report: Making the money work. Geneva, Switzerland: UNAIDS.

The Joint United Nations Programme on HIV \& AIDS Lancet Commission. (2013). How must the health and AIDS architecture be modernized to achieve sustain- 
able global health? London: UNAIDS and Lancet Commission.

Torfing, J., Peters, B. G., Pierre, J., \& Sørensen, E. (2012). Interactive governance. Advancing the paradigm. Oxford: Oxford University Press.

Torfing, J., \& Sørensen, E. (2007). Theoretical approaches to metagovernance. In J. Torfing \& E. Sørensen (Eds.), Theories of democratic network governance (pp. 169-182). Houndsmills, Basingstoke: Palgrave Macmillian.

Wiener, A. (2007a). Contested meanings of norms: A research framework. Comparative European Politics, 5(1), 1-17. doi:10.1057/palgrave.cep.6110107

Wiener, A. (2007b). Contested meanings of norms: A research framework. Comparative European Politics, (5), 1-17.

Wiener, A. (2009). Enacting meaning-in-use: Qualitative research on norms and international relations. Review of International Studies, 35(1), 175-193. doi:10.1017/S0260210509008377

Wiener, A. (2014). Introduction: Contestation as norm- generative social practice. In A. Wiener (Ed.), A theory of contestation (pp. 1-14). Heidelberg, Germany: Springer.

Wiener, A., \& Puetter, U. (2009). The quality of norms is what actors make of it: Critical-constructivist research on norms. Journal of International Law and International Relations, 5(1), 1-15.

World Health Assembly. (2010). Partnerships: report by the Secretariat. Geneva: World Health Organization.

World Health Organization. (2014). WHO and Global Fund strengthen partnership [Press release]. Retrieved from http://www.who.int/about/funding/ who-global-fund-partnership/en

Youde, J. (2012). The World Bank. In J. Youde (Ed.), Global health governance (pp. 46-62). Cambridge: Cambridge University Press.

Zwingel, S. (2012). How do norms travel? Theorizing international women's rights in transnational perspective. International Studies Quarterly, 56(1), 115-129. doi:10.1111/j.1468-2478.2011.00701.x

\section{About the Authors}

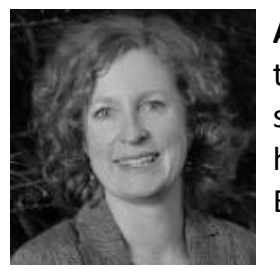

Anna Holzscheiter is Junior Professor of Political Science and International Relations at Freie Universität Berlin and the head of the Freie Universität Berlin \& WZB Berlin Social Science Center Junior Research Group Governance for Global Health. She received her PhD from Freie Universität Berlin and has held fellowship positions at the London School of Hygiene \& Tropical Medicine and the Center for European Studies at Harvard University.

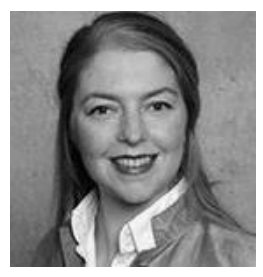

Thurid Bahr is a PhD candidate in Political Science at Freie Universität Berlin and a research fellow with the Freie Universität Berlin \& WZB Berlin Social Science Center Junior Research Group Governance for Global Health. She holds an M.A. in International Relations from Freie Universität Berlin, Humboldt-Universität zu Berlin and Potsdam University.

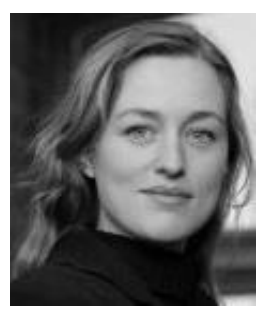

Laura Pantzerhielm is a PhD candidate in Political Science at Freie Universität Berlin and a research fellow with the Freie Universität Berlin \& WZB Berlin Social Science Center Junior Research Group Governance for Global Health. She holds an M.A. in Political Science from Freie Universität Berlin and a Master's degree in International Affairs and Human Rights from Institut d'Études Politiques de Paris (Sciences Po Paris). 